\title{
Preparation and characterization of Zinc metal soap from shea butter (Vitellaria paradoxa)
}

\author{
O. Amos ${ }^{\mathrm{a}, *}$, T. E. Odetoye ${ }^{\mathrm{b}}$, D. S. Ogunniyi ${ }^{\mathrm{b}}$ \\ ${ }^{a}$ Department of Industrial Chemistry, Federal University, Lokoja, P.M.B 1154, Lokoja, Nigeria \\ ${ }^{b}$ Department of Chemical Engineering, University of Ilorin, P.M.B 1515, Ilorin, Nigeria
}

\begin{abstract}
Zinc metal soaps are of great importance in the manufacture of personal care products and other industrial applications. Variations in the soaps and their properties are usually due to the type of oil used in the synthesis. Shea butter (Vitellaria paradoxa), being a valuable industrial raw material, was investigated for the synthesis of zinc metal soap. Locally obtained shea butter was characterized, refined and used to synthesize metal soap of zinc which was characterized. The zinc soap produced exhibited an off-white appearance, $\mathrm{pH}$ of 7.8 , non-foaming, and no free alkalinity present. The functional groups in the soap were confirmed by FTIR.
\end{abstract}

DOI:10.46481/jnsps.2021.238

Keywords: Zinc metal soap, Shea butter, FITR.

Article History :

Received: 2 August 2021

Received in revised form: 7 October 2021

Accepted for publication: 8 October 2021

Published: 29 November 2021

(c)2021 Journal of the Nigerian Society of Physical Sciences. All rights reserved. Communicated by: E. A. Emile

\section{Introduction}

Shea butter is a common fat extracted from the fruit of the African shea tree (Vitellaria paradoxa) that is available in many African countries in the wild [1]. The shea tree fruits are usually collected by women while the fat is obtained traditionally by boiling the kernel in water and scooping the solidified fats after cooling. The butter is also obtained by screw press. It usually presents yellow colour in the raw form with the processed versions being ivory or whitish in colour [2]. Shea butter consists mainly of stearic and oleic fatty acid moieties in its triglycerides [3]. It is widely used in cosmetics as a moisturizer, salve, lotion and medicinal purposes [4]. Shea butter is edible and used as an

\footnotetext{
*Corresponding author tel. no: +2348030677482

Email address: olusegun. amos@fulokja.edu.ng, olusegunamos@yahoo.com (O. Amos)
}

alternate butter in chocolate production [1]. It has been reported as a potential raw material for biodiesel production [5].

Metal soaps are alkaline-earth or heavy-metal long chain carboxylates that are insoluble in water but soluble in non-aqueous solvents. Metal soaps can be represented with a general formula (RCO 2 ) $2 \mathrm{M}$ where $\mathrm{M}$ can be $\mathrm{Zn}, \mathrm{Cd}, \mathrm{Pb}, \mathrm{Ba}, \mathrm{Ca}, \mathrm{Co}$, $\mathrm{Cu}, \mathrm{Al}, \mathrm{Fe}$, e.t.c. and $\mathrm{R}$ is a linear or branched alkyl group [6]. Metal soaps can be produced using any of the following processes: double decomposition (metathesis), direct reaction of carboxylic acid with metal oxides, hydroxides and carbonates and direct reaction of metals with molten fatty acid [7].

Metallic soaps have been found to be useful in various fields. Metal carboxylates are significant in the production of poly vinyl chloride (PVC) which is a vital commercial polymer [8]. Metal carboxylates have been used as green initiators for the ring-opening alternating copolymerization of cyclic anhydride and epoxide [9]. Metal soaps from non- conventional oils can 
also be utilized as paint additives, stabilizer for PVC and for inhibition of corrosion in metals and used as grease [8],colouring vanishes, cosmetics and textiles [10]. The metal soaps of lead, manganese, cobalt and zinc soaps are used in paints to accelerate drying while copper soaps exhibit fungicidal properties. Soaps of zinc, iron, nickel, cobalt and chromium have been applied for the production of water proofing leather and canvas.

Metal soaps are also important in the studies of degradation in paints, their formation resulting in chemo-mechanical damage in historical oil paintings have been reported [11]. The sizes of the metal soap nucleus have been found to influence undesirable metal soap crystallization and growth in historical oil paintings [11, 12]. Hence, there is a need for more research to be directed towards the production and properties of more metal soaps from various oil sources for more suitable applications. Moreso, there is a growing demand for metal soaps as polymer additives [13]. In pharmaceutical field, zinc stearate is a component of the familiar facial or dusting powder and serves as an antiseptic emollient when incorporated with petrolatum. Zinc stearate is also useful as an activator in the accelerated vulcanization of rubber. Utilization of shea butter in the production of metallic soap is a potential means of promoting agro-industrial economy of the African countries where the shea trees abound. The aim of this study is to investigate the preparation of zinc metal soaps from shea butter as a potential industrial raw material for metal soap production. Based on the review of earlier literature, works on zinc soap of shea butter is scarcely reported.

\section{Materials and Methods}

\subsection{Source of material}

The Shea butter (Vitellaria paradoxa) was purchased from Kabba Central Market in Kogi state, Nigeria.

\subsection{Refining of shea butter}

A portion of the shea butter was refined via sequential steps of degumming, neutralization and bleaching in accordance to the methods described in literature $[14,15]$ with little modification of washing the oil several times with hot water during neutralization process to ensure complete removal of the foot.

\subsection{Characterization of the butter}

The physical and chemical properties of the shea butter sample were analyzed according to ASTM standards [16] for the determination of density, specific gravity, acid value, iodine value and saponification value. The functional groups in the shea butter were determined by the Infrared spectrophotometer while the fatty acid constituents of shea butter were also recorded on the Agilent Gas Chromatograph-Mass Spectrometer (Model 7890A GC system,5675C inert MSD with triple axis detector).

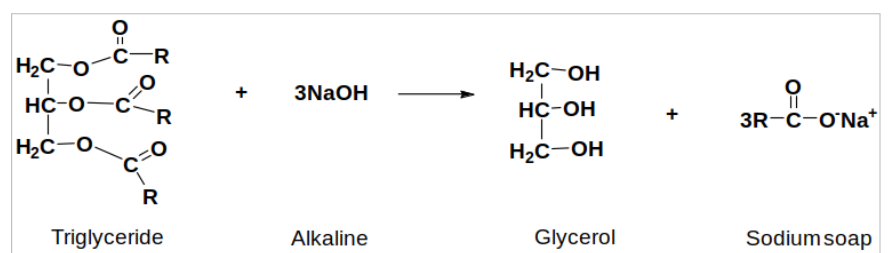

Figure 1: Saponification of oil to form sodium soap

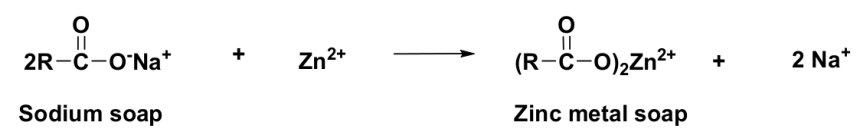

Figure 2: Precipitation of zinc soap

\subsection{Synthesis of Zinc Metal Soap}

Metathesis, which is the mostly used method involves two reactions. Firstly, the aqueous caustic is reacted with fatty acid and subsequently, the reaction of the formed sodium salt with the inorganic salt of the desired metal as shown in Figures 1 and 2.

The saponification reaction is usually carried out at high temperature and in the presence of excess water to dissolve the glycerol formed in the reaction mixture. Consequently, this disallowed the reactions between glycerol (by-product) and the product of metal soap.

The zinc metal soap was prepared by metathesis in aqueous alcoholic solution as summarized in Figure 3, where $R$ in Figures 1 and 2 is stearic acid.
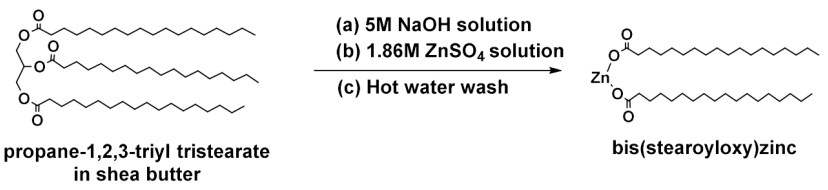

Figure 3: Summary of zinc metal soap formation

$9.2 \mathrm{~g}$ of refined shea butter was dissolved in $10 \mathrm{ml}$ of ethanol at a temperature of $70^{\circ} \mathrm{C}$ followed by the addition of $5 \mathrm{ml}$ of $5 \mathrm{M}$ $\mathrm{NaOH}$ solution. To this mixture, $20 \mathrm{ml}$ of $1.86 \mathrm{M} \mathrm{ZnSO}_{4}$ solution was slowly added with continuous stirring. Upon addition of the solution, the precipitation of the metal soap commenced [8] with little modification). The metal soap that was precipitated was then filtered off and washed with $30 \mathrm{ml}$ hot water $\left(80^{\circ} \mathrm{C}\right)$ and air dried at room temperature for $48 \mathrm{~h}$. The colour of the metal soap was noted and the yield was calculated.

\subsection{Characterization of the Zinc metal soap synthesized}

The properties of the zinc metal soap prepared were determined for $\mathrm{pH}$, free caustic alkalinity, foaming power and stability[8]. As stated by Osmond [17] that FTIR are highly effective for the characterization of metal soaps, the spectra were 
also recorded on Fourier Transform Infra-Red spectrophotometer.

\section{Results and Discussions}

\subsection{Properties of shea butter}

The melting point of the crude shea butter was $32^{\circ} \mathrm{C}$ while its cloud point was found to be $24^{\circ} \mathrm{C}$. Table 1 shows the results obtained for the properties of both the crude and refined shea butter.

The values obtained for shea butter, both refined and unrefined shown in Table 1. When compared with the values obtained by Chiboret al [18],a high acid values of 4.48 and 5.32 for the crude and refined butters respectively indicated that the oil sample contained more free fatty acids thus indicating its exposure to rancidity. The values depend on the method of extraction as the acid values obtained by solvent extraction and cold press methods were 3.50 and $9.54 \mathrm{mg} \mathrm{KOH} / \mathrm{g}$ respectively [19]. The saponification values obtained for the crude and refined samples were $122 \mathrm{mg} / \mathrm{KOH}$ and $150 \mathrm{mg} / \mathrm{KOH}$, respectively. These values were smaller to the one reported by Abdul-Hammed for the solvent extracted $(172.2 \mathrm{mg} / \mathrm{KOH})$ and cold press extracted $(185.7 \mathrm{mg} / \mathrm{KOH})$ methods [20, 21, 22, 23]. A high saponification value shows that the oil is suitable for industrial use, especially for soap making [24]. The desirably low iodine number of shea butter is indicative of the rich saturated fatty acids contents of the oil, which ensure stability against oxidation and rancidity of food prepared from the oil. It also promotes desirable properties for shortening and margarine production.

\subsubsection{Physicochemical properties of prepared zinc metal soap}

Figure 4 shows the metal soap produced.

The properties of the prepared zinc metal soap are as shown in the Table 2.

The appearance of the zinc metal soap prepared is as shown in Figure 4. The metal soap was milky/off-white in colour as a characteristic of zinc salts. Zinc salts are not expected to be coloured since it is not a transition metal. Zinc metal soap being white can be applicable in white paints as pigments and paint driers [8].

The $\mathrm{pH}$ of the metal soap was 7.8 which is neutral in nature and thereby making it safe to handle. The yield of 6.3838 $\mathrm{g}(98 \%)$ is a good one and also a signal of high profitability if

Table 1: Physicochemical properties of crude and refined shea butter sample

\begin{tabular}{ccc}
\hline \hline Properties & Crude Oil & Refined Oil \\
\hline \hline Density $\left(\mathrm{g} / \mathrm{cm}^{3}\right)$ & 0.69 & 0.69 \\
Specific gravity & 0.90 & n.d \\
Acid value & 4.48 & 5.32 \\
Iodine value & 3.04 & 4.568 \\
Saponification value & 122 & 150 \\
\hline n.d - not determined & & \\
\hline
\end{tabular}

Figure 4: Prepared Zinc metal soap sample.

Table 2: The properties of the zinc metal soap prepared

\begin{tabular}{llllll}
\hline \hline $\begin{array}{l}\text { Metal } \\
\text { Soap }\end{array}$ & Colour & $\begin{array}{l}\text { Weight } \\
(\mathrm{g})\end{array}$ & $\mathrm{pH}$ & $\begin{array}{l}\text { Foam } \\
\text { Stability }\end{array}$ & $\begin{array}{l}\text { Free } \\
\text { Caustic } \\
\text { Alkalinity }\end{array}$ \\
\hline $\begin{array}{l}\text { Zinc } \\
\text { metal } \\
\text { soap }\end{array}$ & Milky & 6.38 & 7.8 & No foam & Nil \\
\hline \hline
\end{tabular}

industrially exploited. . The metal soap produced was a mixture of fatty acid carboxylates of zinc, mainly zinc stearate since the major fatty acid components of the shea butter was stearic acid There was no free caustic alkalinity present in the synthesized $\mathrm{d}$ metal soap which indicated that there are no alkalinities left in the soap. The zinc metal soap prepared has poor detergency properties due to its hydrophobic property.

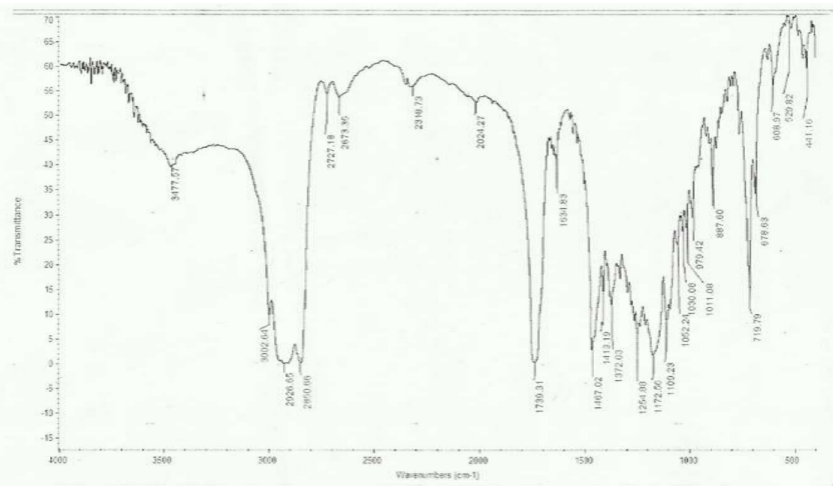

Figure 5: FTIR of refined shea butter.

Figures 5 and 6 showed the infrared spectra of the refined shea butter and that of $\mathrm{Zn}$ metal soap in region 4000 to $500 \mathrm{~cm}^{-1}$ for both samples respectively. From the spectra, the absorption band at $2926 \mathrm{~cm}^{-1}$ was the asymmetry vibration of $\mathrm{CH}_{2}$ stretch, 


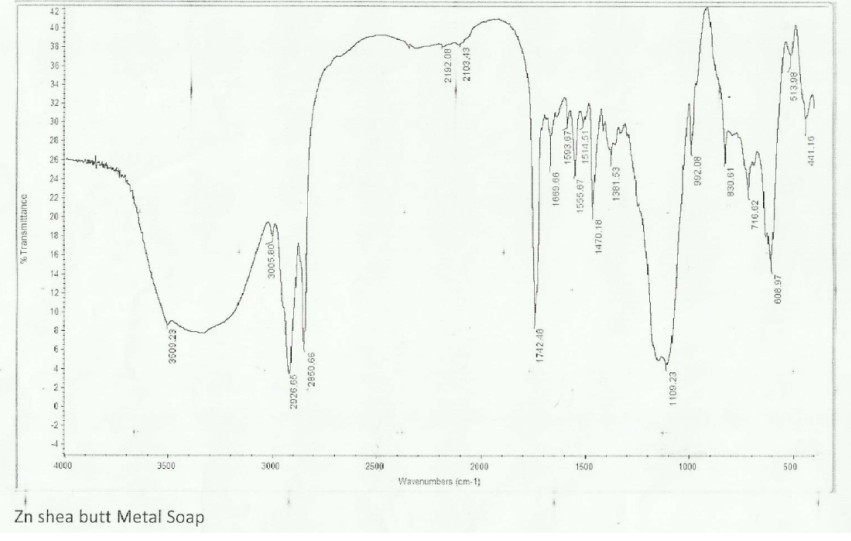

Figure 6: FTIR spectra of zinc metal soap.

while that at $2850 \mathrm{~cm}^{-1}$ was due to the symmetry vibration of $\mathrm{CH}_{2}$ stretch. The $C=O$ stretch of triglyceride linkage was seen at $1742 \mathrm{~cm}^{-1}$. The small absorption band observed at 1669 $\mathrm{cm}^{-1}$ was the characteristic carbonyl stretching band of ester linkage $(C=O)$. It was observed that the absorption at 1710 $\mathrm{cm}^{-1}$ due to $C=O$ of free fatty acids in the shea butter (Figure 5) has disappeared in the metal soap (Figure 6). The $C-H$ absorption of bending vibration of $\mathrm{CH}_{2}$ and $\mathrm{CH}_{3}$ bands was observed at $1470 \mathrm{~cm}^{-1}$. The bands of $\mathrm{CH}_{2}$ bending vibrations were also observed at 1381 and $1109 \mathrm{~cm}^{-1}$. The absorption due to $C-O$ ester bonds were observed at 992,830 and $1097 \mathrm{~cm}^{-1}$ The $\mathrm{CH}_{2}$ rocking vibration can be clearly seen at $722 \mathrm{~cm}^{-1}$. The FTIR spectra confirmed the functional groups fatty acid carboxylates of zinc produced.

\section{Conclusion}

In this study, the preparation of zinc metal soap from shea butter was successfully done using the double decomposition (metathesis) method. The shea butter metal soap produced exhibited desirable characteristic metal soap colour, hydrophobic and free caustic alkalinity properties. FTIR spectra confirmed the functional groups of the soap. Successful production of metallic soap from shea butter establishes its potential use as an industrial raw material in addition to the traditional uses. More attention is to be paid to industrial application of shea butter in African communities towards the development of the agro-industrial economy. Further work can be done on the production of high purity zinc stearate from shea butter.

\section{References}

[1] A. J. Dijkstra, "Vegetable Oils: Types and Properties", in Encyclopedia of Food and Health" (2016) 381.

[2] . G. A. Yonas, E. A. Shimelis \& A. F. Sisay, "Effect of processing factors on Shea (Vitellaria paradoxa) butter extraction", LWT - Food Science and Technology 66 (2016) 172.

[3] O. Atolani, E. T. Olabiyi, A. A. Issa, H. T. Azeez, E. G. Onoja, O. S. Ibrahim, M. F. Zubair, O. S. Oguntoye, \& G. A. Olatunji, "Green synthesis and characterisation of natural antiseptic soaps from the oils of underutilised tropical seed", Sustainable Chemistry and Pharmacy 4 (2016) 32.
[4] W. N. Muhammad, M. I. Muhammad, A. S. Garba, \& H. M. Ghazal, "Antibacterial Activity of Vitellaria paradoxa Seed Oil Extract and Honey Against Bacterial Isolates from Wound Infection", International Journal of Biological, Physical and Chemical Studies (JBPCS) 1 (2019) 16.

[5] E. Betiku, S. S. Okunsolawo, S. O. Ajala, \& O. S. Odedele, "Performance evaluation of artificial neural network coupled with generic algorithm and response surface methodology in modeling and optimization of biodiesel production process parameters from shea tree (Vitellaria paradoxa) nut butter", Renewable Energy 76 (2015) 408.

[6] O. M. Folarin, I. C. Eromosele, \& C. O. Eromosele, "Relative thermal stability of metal soaps of Ximenia americana and Balanites aegyptiaca seed oils", Scientific Research and Essays 6 (2011) 1922.

[7] M. Gonen, D. Balkose, F. Inal, \& S. Ulku, "Zinc Stearate Production by Precipitation and Fusion Processes" Industrial \& Engineering Chemistry Research 14 (2005) 1627.

[8] E. K. Ossai (2014), "Preparation and Characterization of Metal Soaps of Cocos Nucifera Seed Oil", Journal of Applied Sciences and Environmental Management 18 (2014) 359.

[9] C. Chong-Min, X. Xiaowei, J. He-Yuan, W. Bin, P. Li, L. Yi, Y. Sheng, "Alkali Metal Carboxylates: Simple and Versatile Initiators for RingOpening Alternating Copolymerization of Cyclic Anhydrides/Epoxides", Macromolecules 54 (2021) 713.

[10] O. M. Folarin \& O. N. Enikanoselu, "Evaluation of the Effect of Temperature on the Stability of Metal Soaps of Trichosanthes cucumerina seed oil", Journal of Applied Sciences and Environmental Management 14 (2010) 69.

[11] G. J. Eumelen, E. Bosco, A. S. Suiker, A. Loon, \& P. D. Iedema, "A computational model for chemo-mechanical degradation of historical oil paintings due to metal soap formation", Journal of the Mechanics and Physics of Solids 132 (2019) 103683.

[12] S. Garrappa, E. SilvieSvarcova, P. Bezdicka, \& D. Hradil, "Initial stages of metal soaps formation in model paints: The role of humidity", Microchemical Journal 156 (2020) 104842.

[13] Baerlocher, "Baerlocher USA to expand metal soap production capacity to meet growing demand", Additives for Polymers 3 (2017) 6. https://doi.org/10.1016/S0306-3747(17)30039-8.

[14] T. E. Odetoye, D. S. Ogunniyi, \& G.A. Olatunji "Refining and characterization of under-utilised seed oil of Parinari polyandra Benth for industrial utilization", Nigerian Journal of Pure and Applied Sciences 27 (2014) 2538.

[15] W. Haas \& M. Mittelbach, "Detoxification experiment with seed oils from from Jatropha curca", Industrial Crops and Products 12 (2000) 111.

[16] ASTM standard methods "Standard Test Method for Fatty Acid Composition" 1983.

[17] G. Osmond, "Zinc Soaps: An Overview of Zinc Oxide Reactivity and Consequences of Soap Formation in Oil-Based Paintings. In: Casadio F. et al. (eds) Metal Soaps in Art. Cultural Heritage Science." Springer, Cham. (2019), https://doi.org/10.1007/978-3-319-90617-1_2

[18] B. S. Chibor, D. B. Kiin-Kabari, \& J. Eke-Ejiofor, "Physicochemical Properties and Fatty Acid Profile of Shea Butter and Fluted Pumpkin Seed Oil, a Suitable Blend in Bakery Fat Production". International Journal of Nutrition and Food Sciences 6 (2017) 122, doi:10.11648/j.ijnfs.20170603.1,

[19] M. Abdul-Hammed, A. O. Jaji, \& S. A. Adegboyega, "Comparative studies of thermophysical and physicochemical properties of shea butter prepared from cold press and solvent extraction methods", Journal of King Saud University - Science 32 (2020) 2343.

[20] E. D. Owen, \& K. J. Msayib, "Catalyzed degradation of poly(vinyl chloride) III Zinc (II) chloride catalysis", Journal of Polymer Science A 27 (1989) 399.

[21] R. M. Maryudi, A. H. Yunus, A. H. Nour \& M. H. Abidin, "Synthesis and Characterization of Manganese Carboxylates", Journal of Applied Sciences 9 (2009) 3156.

[22] T. Ismail, A. I. Ashraf, \& K. Hüseyin, International Journal of food propertied 20 (2017) S790.

[23] E. A. Essien, S. A. Umoren, E. E. Essien, \& A. P. Udoh, Journal of Materials and Environmental Science 3 (2012) 477.

[24] R. Bacalogulu \& M. Fisch, "Degradation and stabilization of poly(vinyl chloride) 11. Kinetics of the thermal degradation of poly (vinyl chloride)", Journal of Polymer Degradation and Stability 45 (1994) 325. 